\title{
Habitat modelling locates nesting areas of the Endangered Black-capped Petrel Pterodroma hasitata on Hispaniola and identifies habitat loss
}

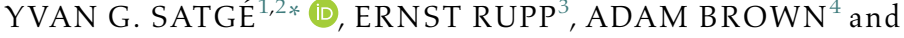 \\ PATRICK G. R. JODICE ${ }^{5,2}$ \\ ${ }^{1}$ South Carolina Cooperative Fish and Wildife Research Unit, Clemson, SC, USA. \\ ${ }^{2}$ Department of Forestry and Environmental Conservation, Clemson University, Clemson, SC, \\ USA. \\ ${ }^{3}$ Grupo Jaragua, Santo Domingo, Dominican Republic. \\ ${ }^{4}$ Environmental Protection In the Caribbean, Sint Maarten, Dutch West Indies. \\ ${ }^{5}$ U.S. Geological Survey, South Carolina Cooperative Fish and Wildlife Research Unit, Clemson, \\ SC, USA.
}

Author for correspondence; email:ysatge@clemson.edu

(Received 10 March 2020; revision accepted 13 August 2020)

\section{Summary}

The Black-capped Petrel or Diablotin Pterodroma hasitata has a fragmented and declining population estimated at c.1,ooo breeding pairs. On land, the species nests underground in steep ravines with dense understorey vegetation. The only confirmed breeding sites are located in the mountain ranges of Hispaniola in the Caribbean, where habitat loss and degradation are continuing threats. Other nesting populations may still remain undiscovered but, to locate them, laborious in situ nest searches must be conducted over expansive geographical areas. To focus nest-search efforts more efficiently, we analysed the environmental characteristics of Black-capped Petrel nesting habitat and modeled suitable habitat on Hispaniola using openly available environmental datasets. We used a univariate generalized linear model to compare the habitat characteristics of active Blackcapped Petrel nests sites with those of potentially available sites (i.e. random pseudo-absences). Elevation, distance to coast, and the influence of tree cover and density emerged as important environmental variables. We then applied multivariate generalized linear models to these environmental variables that showed a significant relationship with petrel nesting activity. We used the top performing model of habitat suitability model to create maps of predicted suitability for Hispaniola. In addition to areas of known petrel activity, the model identified possible nesting areas for Black-capped Petrels in habitats not previously considered suitable. Based on model results, we estimated the total area of predicted suitable nesting habitat for Black-capped Petrels on Hispaniola and found that forest loss due to hurricanes, forest fires, and encroachment from agriculture had severely decreased availability of predicted suitable habitat between 2000 and 2018 .

\section{Resumen}

El Diablotín Pterodroma hasitata tiene una población fragmentada y en declive estimada a cerca de 1,00o parejas reproductoras. En tierra la especie anida en madrigueras localizadas en barrancos 
escarpados con un sotobosque denso. Los únicos sitios de anidamiento confirmados se localizan en las montañas de la Isla de Santo Domingo en el Caribe, donde la pérdida y la degradación del hábitat forman amenazas continuas. Es posible que existan otros sitios de anidamiento pero, para localizarlos, se deben conducir búsquedas laboriosas in situ en áreas geográficas extensas. Para poder enfocar los esfuerzos de búsqueda más efectivamente, analizamos las características ambientales del hábitat de anidamiento del Petrel diablotín y modelizamos el hábitat disponible en la Española utilizando bases de datos ambientales públicamente disponibles. Comparamos por regresión logística las características del hábitat de los sitios de anidamiento activos del Diablotín con las de sitios potencialmente disponibles (seudo-ausencias aleatorias). La altitud, distancia a la costa, y la influencia y la densidad de cobertura arbórea aparecieron como variables ambientales importantes. Luego aplicamos modelos lineares generalizados a las variables ambientales que tenían una relación significativa a la actividad de anidamiento del Diablotín. Utilizamos el modelo de mayor rendimiento para construir un modelo adecuado del hábitat y crear mapas adecuados para la Isla de Santo Domingo. Además de las zonas de actividad ya conocidas, el modelo identificó zonas de posible anidamiento en hábitats que no eran considerados como adecuados para el Diablotín. Utilizando los resultados del modelo, estimamos la superficie total del hábitat de anidamiento potencial para el Diablotín en la Isla de Santo Domingo y encontramos que la pérdida de bosques debido a huracanes, fuegos forestales y el avance de la frontera agrícola severamente disminuyeron la disponibilidad del hábitat adecuado entre el 2000 y el 2018.

\section{Résumé}

Le Pétrel diablotin Pterodroma hasitata a une population fragmentée et en déclin estimée à env. 1,00o couples nicheurs. A terre, l'espèce niche dans des terriers situés sur des ravins escarpés avec une végétation de sous-bois dense. Les seuls sites de nidifications confirmés sont situés dans les montagnes d'Hispaniola aux Caraïbes, où la perte et la dégradation de l'habitat sont des menaces persistantes. Il est possible que d'autres populations nicheuses subsistent mais, pour les localiser, des recherches laborieuses doivent être conduites in situ sur de vastes aires géographiques. Afin de concentrer les efforts de recherche plus efficacement, nous avons analysé les caractéristiques environnementales de l'habitat de nidification du Pétrel diablotin et modélisé l'habitat disponible sur Hispaniola en utilisant des jeux de données environnementales publics. Nous avons comparé par régression logistique les caractéristiques d'habitat de sites de nidification actifs du Pétrel diablotin avec celles de sites potentiellement disponibles (i.e. pseudo-absences aléatoires). L'altitude, la distance à la côte, et l'influence et la densité de la couverture végétale étaient des variables environnementales importantes. Nous avons ensuite appliqué des modèles linéaires généralisés aux variables environnementales qui étaient significativement liées à l'activité de nidification du Pétrel diablotin. Nous avons utilisé le meilleur modèle pour construire un modèle de convenance de l'habitat de nidification et pour créer des cartes de convenance pour Hispaniola. En plus des zones d'activité de nidification connues, le modèle a identifié des zones de nidification possibles dans des habitats considérés jusqu'alors comme n'étant pas convenables au Pétrel diablotin. En utilisant les résultats du modèle, nous avons estimé la surface totale d'habitat de nidification convenable pour le Pétrel diablotin sur Hispaniola et nous avons trouvé que la perte de forêts due aux ouragans, aux feux de forêts et à l'empiètement de l'agriculture ont sévèrement diminué la disponibilité de l'habitat convenable entre 2000 et 2018.

Keywords: Habitat modelling, endangered species, seabird 


\section{Introduction}

As seabirds are experiencing worldwide decreases in population (Croxall et al. 2012, Paleczny et al. 2015, Dias et al. 2019), current information on breeding distributions is needed to better estimate population trends and to focus conservation actions (Croxall et al. 2012). In particular, gadfly petrels of the genus Pterodroma are experiencing some of the most rapid declines of any seabird species (Croxall et al. 2012, Dias et al. 2019) but remain among the least studied groups of seabirds (Ramos et al. 2017). Although they range widely over tropical, subtropical, temperate and subantarctic pelagic waters of each ocean basin, their breeding populations are limited to a comparatively small number of oceanic archipelagoes, to which they are mostly endemic (Warham 1990). Gadfly petrels are predominantly nocturnal on land and often breed in inaccessible places in small numbers, thus impeding the collection of basic data on breeding distributions that would allow effective conservation actions.

The Black-capped Petrel Pterodroma hasitata (known regionally as Diablotin) is a medium-size gadfly petrel endemic to the Caribbean. The species has a declining population and is considered 'Endangered' throughout its range (BirdLife International 2016). Population estimates based on at-sea observations range from 2,000 to 4,00o individuals, with a fragmented breeding population estimated at 500 to 1,00o pairs (Goetz et al. 2012, Simons et al. 2013, BirdLife International 2018). Once widespread in the Caribbean (Collar et al. 1992), currently the only confirmed breeding areas are located on the island of Hispaniola (Simons et al. 2013), although recent surveys suggest possible nesting populations in Dominica (Brown 2015), Jamaica (Brown 2016) and Cuba (Yasit Segovia, BioEco and Nicasio Viña Davila, Corridor Biologico del Caribe pers. comm., 2020). All known nesting sites are in mountainous areas 1,500-2,000 $\mathrm{m}$ above sea level. There, Black-capped Petrels nest in the thick and mesic understorey of steep montane forests and excavate burrows in soil or karstic crevasses.

Our current understanding of Black-capped Petrel conservation and ecology suggest that, unlike most other species of petrels (Rodríguez et al. 2019), the Black-capped Petrel is predominantly affected by changes to and threats within its breeding habitat (Goetz et al. 2012, U.S. Fish and Wildlife Service 2018). Threats include a mix of direct and indirect habitat disruption driven by anthropogenic activities. Habitat loss is occurring via deforestation, forest fires, agricultural encroachment (including illegal agriculture within the boundaries of national parks) and, particularly in Haiti, firewood collection and charcoal production (Simons et al. 2013). Deterioration of habitat quality is occurring via predation of adults and juveniles at nest sites by introduced mammalian predators (Goetz et al. 2012, Rupp pers. obs.) and collisions of adult petrels with lighted telecommunication towers erected on mountaintops (Goetz et al. 2012, Simons et al. 2013). Due in large part to these threats, the U.S. Fish and Wildlife Service (2018) predicted that the two major breeding areas on Hispaniola are likely to face extirpation by 2070 and, if no additional nest sites are found, this would represent a potential loss of up to $85-95 \%$ of the currently known breeding population. Although surveys are underway to locate unidentified nesting areas, such efforts are complex and labour-intensive, involving terrestrial radar surveys near suspected breeding areas, acoustic surveys using automated recording units to confirm petrel activity, and intensive nest searches at active locations. To date, these methods have resulted in the discovery of two additional nesting areas.

Therefore, to aid conservation efforts for the Black-capped Petrel, we developed a predictive habitat suitability model for nesting Black-capped Petrels on the island of Hispaniola. Our goal is that the model be used to support the identification of target areas for in situ nest-search efforts per recommendations of the International Black-capped Petrel Working Group (IBCPWG 2018). Species distribution models such as the one developed herein can use the relationship between a species's observed occurrence and environmental predictor variables to quantify its habitat requirements, which can then be extrapolated over wide geographical extents (Elith and Leathwick 2009). Our objectives were to 1 ) describe important habitat characteristics for breeding Black-capped Petrels on Hispaniola, 2) identify unknown areas where nesting could occur, 3) quantify the 
amount of remaining available habitat predicted by the model, and 4) quantify the amount of predicted habitat impacted by forest loss. We specifically chose to use openly available environmental datasets to ensure that all stakeholders could access the datasets and further develop the model once new nesting sites have been located.

\section{Methods}

\section{Study extent and data collection}

To date, all known nests $(n=81)$ of Black-capped Petrels found since the rediscovery of the species in the 1960s (Wingate 1964) have been located on the island of Hispaniola, in four distinct areas in three mountain ranges (Figure I): 29 nests were found in the La Visite nesting area, La Visite mountain range, Haiti, during the 2018 nesting period (Jean et al. 2018); 43 nests were found in the Morne Vincent $(n=3)$ and Loma del Toro $(n=40)$ nesting areas, western Sierra de Bahoruco mountain range, in Haiti and the Dominican Republic, between the 2011 and 2018 nesting periods; five nests were found in the Loma Quemada nesting area, eastern Sierra de Bahoruco, Dominican Republic, during the 2015 nesting period; and four nests were found in the Valle Nuevo nesting area, Cordillera Central mountain range, Dominican Republic, during the 2018 and 2019 nesting periods. Most nesting areas are located within the boundaries of the La Visite, Sierra de Bahoruco or Valle Nuevo national parks. For the purposes of this study, we used all 81 Black-capped Petrel nest locations. Except for the three nests in the Morne Vincent nesting area and three in the Loma del Toro nesting area, all nests were monitored during the 2019 nesting season, and $>90 \%$ were found to be active.

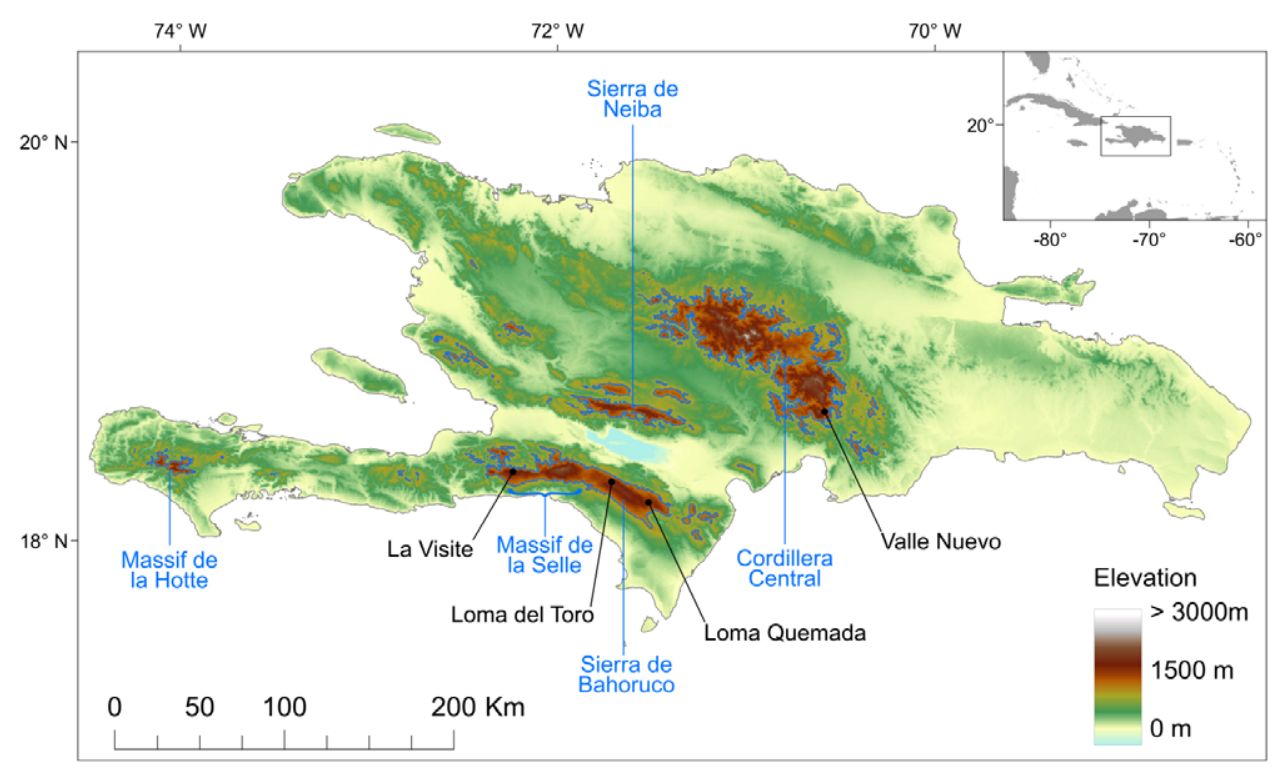

Figure 1. Topography of the island of Hispaniola and location of known Black-capped Petrel nesting areas. Black dots show the locations of Black-capped Petrel nest sites used in this study. Blue polygons delineate the areas above 1,200 $\mathrm{m}$ above sea level used to randomly select pseudoabsence locations. The major mountain ranges are indicated in blue. Insert locates the island of Hispaniola within the Caribbean. A color version of this figure may be found in the electronic version of this article. 


\section{Modelling overview}

Detailed methods may be found in Appendix $\mathrm{S}_{1}$ in the online supplementary materials. Unless mentioned otherwise, we performed all statistical and geographic computing in program $R$. Because we could not confirm if observed absences at search areas were true absences or failures to detect presence, we could not use a presence-absence framework to estimate and locate suitable nesting habitat. Instead, we followed methods in Troy et al. (2014) and used a univariate generalized linear model (i.e. logistic regression) to compare the habitat characteristics of known Blackcapped Petrel nests sites with those of potentially available sites (i.e. presence and pseudo-absence sites, respectively). We located 500 pseudo-absence sites at random in all mountain ranges on Hispaniola above 1,200 m (Figure I), an apparent threshold for use as nest sites by the species (Simons et al. 2013). This included random pseudo-absence locations that were more likely to be true absences, in areas not sampled for petrels but where radar surveys showed that there was no breeding activity (Cordillera Central and Sierra de Neiba; Brown 2017). All pseudo-absence sites were located $\geq 500 \mathrm{~m}$ from presence sites. We partitioned presence and pseudo-absence sites into two groups for subsequent analysis: a training dataset containing $80 \%$ of both groups, which was used to train the statistical models, and a validation dataset containing the remaining $20 \%$ of sites, which was used to assess the fit of the models. Black-capped Petrels often nest in clusters of 5-10 burrows within 100-200 m; therefore, to avoid risks of pseudo-replication and to better quantify environmental data at nest sites, we created buffers of $50 \mathrm{~m}$ radius around each presence site and combined any overlapping buffers into presence polygons. Since more than one nest can occur in a polygon, adjacent nest sites were combined and the number of polygons is less than the number of nests. We used the same methodology to create and combine any overlapping pseudo-absence 50-m buffers into pseudo-absence polygons. Finally, we reduced the effect of differences in sample size between the presence and pseudo-absence groups by weighting them to simulate an equal number of presence and pseudo-absence sites, such that the total weight of the presence data was the same as the total weight of the pseudo-absence data (Barbet-Massin et al. 2012).

To allow for future reproducibility in the greater Caribbean by local stakeholders, we estimated habitat characteristics from open-access environmental datasets (rasters) readily available for the region (Table I). Variables were broadly classified as static (elevation, distance to coast, distance to ridgeline, slope, aspect, flow accumulation) and dynamic (Enhanced Vegetation Index, EVI; Leafarea Index, LAI; evapotranspiration; primary productivity; percentage tree cover, hereafter tree cover; aboveground live woody biomass density, hereafter woody biomass; mean wind speeds; and monthly average radiance). Satellite-derived vegetation datasets such as EVI and LAI may overestimate areas with low or no vegetation (such as bare soil, rocks or snow): indeed, these areas sometimes reflect light in the wavelengths recorded by satellites and may appear in raster datasets as if vegetation is present (i.e. false positives; Satgé pers. obs.). Therefore, we created a new dataset as a composite of tree cover for the year 2000 (Global Forest Watch 2019a) and 16-day Enhanced Vegetation Index, rescaled between o and I (tree cover-EVI). Finally, we resampled all environmental rasters to match the resolution of the digital elevation model (DEM: $90 \mathrm{~m} \mathrm{x} 90 \mathrm{~m}$; bilinear interpolation).

We calculated the habitat characteristics of presence and pseudo-absence sites by averaging each environmental variable within a buffer of 50-m radius located at each site (Troy et al. 2014). We first tested environmental variables individually using univariate logistic regressions and retained the variables that (I) showed a significant relationship with the presence of active petrel sites at $P \leq$ o.01 (Table 2); and (2) were not collinear with other environmental predictors. We checked for collinearity using a generalized variance-inflation factor. Vegetation variables showed strong collinearity among themselves and with the composite dataset tree cover-EVI. Therefore, we only retained tree cover-EVI because it best represented actual field conditions. Elevation and mean wind speeds also showed collinearity: we omitted the wind variable because it had the least significant regression coefficient $\left(\mathrm{P}_{\text {Mean Wind }}=0.05\right.$ vs. $\left.\mathrm{P}_{\text {Elevation }}<0.001\right)$. Variance-inflation factors for the remaining variables were $<1.8$, which suggested that these variables could be included in the 
Table 1. Environmental variables used to estimate the characteristics of Black-capped Petrel nesting habitat on Hispaniola.

\begin{tabular}{|c|c|c|c|}
\hline Variable & Dataset & Spatial resolution & $\begin{array}{l}\text { Temporal } \\
\text { resolution }\end{array}$ \\
\hline Elevation (m) & WWF HydroSHEDS Void-filled DEM & $\begin{array}{l}3 \text { arc-seconds (9om at } \\
\text { equator) }\end{array}$ & - \\
\hline Distance to coast $(\mathrm{km})$ & $\begin{array}{l}\text { Prepared from Global Self-consistent, Hierarchical, High-resolution Shoreline } \\
\text { (GSHHS_h_L1; Wessel and Smith 2017) }\end{array}$ & $\begin{array}{l}3 \text { arc-seconds ( } 90 \mathrm{~m} \text { at } \\
\text { equator) }\end{array}$ & - \\
\hline Distance to ridgeline $(\mathrm{m})$ & Prepared from WWF HydroSHEDS Void-filled DEM & $\begin{array}{l}3 \text { arc-seconds ( } 90 m \text { at } \\
\text { equator) }\end{array}$ & - \\
\hline Slope steepness (\%) & Prepared from WWF HydroSHEDS Void-filled DEM & $\begin{array}{l}3 \text { arc-seconds (9om at } \\
\text { equator) }\end{array}$ & - \\
\hline Aspect $\left({ }^{\circ}\right)$ & Prepared from WWF HydroSHEDS Void-filled DEM & $\begin{array}{l}3 \text { arc-seconds ( } 90 \mathrm{om} \text { at } \\
\text { equator) }\end{array}$ & - \\
\hline Flow accumulation & WWF HydroSHEDS Flow Accumulation & $\begin{array}{l}15 \text { arc-seconds (50om } \\
\text { at equator) }\end{array}$ & - \\
\hline Enhanced Vegetation index & MOD13 $A_{1}:$ MODIS/Terra Vegetation Index & $500 \mathrm{~m}$ & 16-day \\
\hline Leaf-area index & $\mathrm{MCD}_{15} \mathrm{~A}_{3} \mathrm{H}:$ MODIS/Terra+ Aqua Leaf Area Index & $500 \mathrm{~m}$ & 4-day \\
\hline Evapotranspiration $\left(\mathrm{kg} \mathrm{m}^{-2} 8 \mathrm{day}^{-1}\right)$ & MOD16A2: MODIS/Terra Net Evapotranspiration & $500 \mathrm{~m}$ & 8-day \\
\hline Primary Productivity $\left(\mathrm{kg} \mathrm{C} \mathrm{m}^{-2}\right)$ & $\mathrm{MOD}_{17} \mathrm{~A}_{3} \mathrm{H}: \mathrm{MODIS} /$ Terra Net Primary Production & $500 \mathrm{~m}$ & yearly \\
\hline Tree cover* $(\%)$ & Global Forest Watch Tree Cover (2000); Global Forest Watch 2019a & $30 \mathrm{~m}$ & - \\
\hline $\begin{array}{l}\text { Tree cover-Enhanced Vegetation } \\
\text { Index }\end{array}$ & $\begin{array}{l}\text { Prepared from Tree cover (2000) (Global Forest Watch 2019a) and MOD13A1: } \\
\text { MODIS/Terra Vegetation Index }\end{array}$ & $500 \mathrm{~m}$ & 16-day \\
\hline $\begin{array}{l}\text { Aboveground live woody biomass } \\
\text { density }\left(10^{9} \mathrm{~g} \mathrm{ha}^{-1}\right)\end{array}$ & $\begin{array}{l}\text { Global Forest Watch Aboveground live woody biomass density; Global Forest Watch } \\
(2019 \mathrm{c})\end{array}$ & $\begin{array}{l}0.9 \text { arc-seconds (3om at } \\
\text { equator) }\end{array}$ & - \\
\hline Mean wind speed $\left(\mathrm{m} \mathrm{s}^{-1}\right)$ & WorldClim V.2; climatology; Fick and Hijmans (2017) & $\begin{array}{l}30 \text { arc-seconds ( } 1 \mathrm{~km} \text { at } \\
\text { equator) }\end{array}$ & monthly \\
\hline Light sources (nanoWatt $\mathrm{cm}^{-2} \mathrm{sr}^{-1}$ ) & VIIRS Average Radiance, corrected for stray light; median & $\begin{array}{l}15 \text { arc-seconds ( } 500 m \\
\text { at equator) }\end{array}$ & monthly \\
\hline
\end{tabular}

* Tree cover was not used as a stand-alone predictor in analyses but was used to compute the variable Tree cover-Enhanced Vegetation Index. 
Table 2. Characteristics of environmental variables at Black-capped Petrel nesting sites and pseudo-absence sites on Hispaniola. Mean, standard deviation (SD), and range (Min. = minimum values, Max. $=$ maximum values) and p-values of individual univariate logistic regressions are provided. Variables that showed a significant difference between presence and pseudo-absence sites are shown in italics. Variables that were retained to compute the habitat suitability model are shown in bold (others removed due to collinearity; see Methods).

\begin{tabular}{|c|c|c|c|c|c|c|c|c|c|c|}
\hline \multirow[b]{2}{*}{ Covariate } & \multicolumn{4}{|c|}{ Petrel sites $(n=23)$} & \multicolumn{4}{|c|}{ Random sites $(n=400)$} & \multirow[b]{2}{*}{$P$-value } & \multirow[b]{2}{*}{ Regression coefficient } \\
\hline & Mean & SD & Min. & Max. & Mean & SD & Min. & Max. & & \\
\hline Elevation (m) & 2082.0 & 217.2 & 1641.0 & 2330.0 & 1603.7 & 334.1 & 1189.5 & 2782.0 & 0.0004 & $5.06 \times 10^{-3}$ \\
\hline Distance to coast $(\mathrm{km})$ & $25 \cdot 4$ & $3 \cdot 4$ & 14.7 & 30.8 & 51.6 & 25.0 & 8.6 & 89.2 & 0.0063 & $-9.51 \times 10^{-5}$ \\
\hline Distance to ridgeline (m) & 452.1 & 237.0 & 110.6 & 915.0 & 463.6 & $319 \cdot 7$ & 0.0 & 1583.1 & 0.89 & $1.47 \times 10^{-4}$ \\
\hline Slope $(\%)$ & $37 \cdot 7$ & 22.3 & $7 \cdot 9$ & 81.4 & 30.9 & 16.7 & 0.6 & 88.3 & 0.26 & $1.80 \times 10^{-2}$ \\
\hline Aspect $\left({ }^{\circ}\right)$ & 144.8 & 137.8 & 0.3 & 358.5 & 180.7 & 103.2 & 0.6 & 358.5 & 0.33 & $-2.47 \times 10^{-3}$ \\
\hline Flow accumulation & 6.8 & 10.1 & 1.0 & 36.5 & 7.2 & 23.2 & 1.0 & 248.4 & 0.93 & $-1.42 \times 10^{-3}$ \\
\hline Enh. Veg. Index & 0.30 & 0.03 & 0.25 & 0.36 & 0.37 & 0.06 & 0.24 & 0.53 & 0.0015 & -32.2 \\
\hline Leaf-area Index & 2.02 & 0.6 & 1.04 & 3.05 & 2.30 & 1.31 & 0.52 & $5 \cdot 32$ & 0.338 & $-2.59 \times 10^{-1}$ \\
\hline Evapotransp. $\left(\mathrm{kg} \mathrm{m}^{-} 8\right.$ day $\left.^{-1}\right)$ & 21.54 & 4.65 & 13.60 & 28.80 & 23.68 & 6.16 & 10.25 & $35 \cdot 45$ & 0.020 & $-7.22 \times 10^{-2}$ \\
\hline Prim. Productivity $\left(\mathrm{kg} \mathrm{C} \mathrm{m}^{-2}\right)$ & 0.96 & 0.48 & 0.54 & 1.70 & 1.17 & 0.42 & 0.41 & 1.94 & 0.12 & -1.07 \\
\hline Tree Cover-EVI* & 0.73 & 0.07 & 0.55 & 0.81 & 0.53 & 0.21 & 0.15 & 0.82 & 0.0074 & 10.3 \\
\hline Wood biomass $\left(10^{9} \mathrm{~g} \mathrm{ha}^{-1}\right)$ & 163.8 & $25 \cdot 7$ & 110.5 & $199 \cdot 3$ & 114.5 & $67 \cdot 7$ & 0.0 & 234.2 & 0.016 & $2.18 \times 10^{-2}$ \\
\hline Mean wind $\left(\mathrm{m} \mathrm{s}^{-1}\right)$ & 2.9 & 0.2 & 2.6 & $3 \cdot 3$ & 2.7 & 0.5 & 1.7 & $4 \cdot 7$ & 0.056 & 1.81 \\
\hline Radiance (nanoWatt $\mathrm{cm}^{-2} \mathrm{sr}^{-1}$ ) & 0.2 & 0.0 & 0.2 & 0.2 & 0.3 & 1.8 & 0.1 & 35.1 & 0.093 & $-24 \cdot 3$ \\
\hline
\end{tabular}

* Tree Cover - Enhanced Vegetation Index 
Table 3. Characteristics of the candidate models, and Intercept-only model, for Black-capped Petrel nesting habitat suitability on Hispaniola. The best performing model $(\triangle \mathrm{AICc}<2)$ is shown in bold.

\begin{tabular}{|c|c|c|c|c|}
\hline Model & Rank & $\mathrm{AICc}$ & $\triangle \mathrm{AICc}$ & AICc weight \\
\hline I + Elevation + DistanceCoast + TreeCover-EVI & $\mathbf{I}$ & -138.13 & 0.00 & 0.990 \\
\hline $1+$ Elevation + DistanceCoast & 2 & -128.98 & 9.16 & 0.010 \\
\hline I + DistanceCoast + TreeCover-EVI* & 3 & -113.13 & 25.00 & 0.000 \\
\hline I + Elevation + TreeCover-EVI ${ }^{*}$ & 4 & -112.49 & 25.64 & 0.000 \\
\hline $1+$ Elevation & 5 & $-107 \cdot 57$ & 30.57 & 0.000 \\
\hline $1+$ DistanceCoast & 6 & -88.96 & 49.18 & 0.000 \\
\hline$I+$ TreeCover-EVI & 7 & -85.65 & 52.48 & 0.000 \\
\hline I (Intercept) & 8 & $-67 \cdot 55$ & 70.58 & 0.000 \\
\hline
\end{tabular}

* Tree Cover - Enhanced Vegetation Index

generalized linear model without large risk of collinearity (Quinn and Keough 2002). The retained environmental predictors were: elevation, distance to coast, and tree cover-EVI.

We then ran generalized linear models which included all possible single-level combinations of the three significant predictors, with a binomial logistic structure with presence vs pseudo-absence as the response variable. Limiting the number of model predictors to three environmental variables helped avoid overly complex candidate models that could impair functional accuracy (Warren et al. 2020). We compared candidate models using Akaike's Information Criterion for small sample sizes (AICc): a single model had a $\triangle$ AICc value $<2$ and an Akaike weight $>0.9$; therefore, we considered it the top performing model (Table 3). We used a continuous Boyce Index (Hirzel et al. 2006) to estimate how much the model predictions differed from random expectation. Moreover, species distribution models with large spatial extent and high spatial autocorrelation may incorrectly appear to have good discrimination capabilities (Hijmans 2012). To address this issue, we calculated the amount of spatial sorting bias, which ranges from zero (highly correlated dataset) to one (uncorrelated dataset; Hijmans 2012). As advised by Lobo et al. (2008), we also calculated the sensitivity (i.e. true positive rate, or proportion of instances of presence correctly predicted as presence), specificity (i.e. 'true' negative rate, which, in our study, refers to the proportion of instances of pseudo-absence predicted as absence), and the threshold of specificity-sensitivity (maximum of the sum of the sensitivity and the specificity; Hijmans 2012).

Finally, we applied the regression equation for the final habitat suitability model to the raster layers of the retained environmental variables to produce a map of predicted habitat suitability for the island of Hispaniola, with cell values ranging from zero (habitat not suitable for Black-capped Petrel nesting) to one (habitat highly suitable for Black-capped Petrel nesting). We assessed the validity of the model by calculating predicted suitability values for the presence and pseudoabsence sites in the validation dataset and compared the distribution of suitability values between both groups using an F-test. In addition, we used an independent dataset of locations where petrel activity was recorded by acoustic monitors (McKown et al. 2016, Fleishman and McKown 2017), and a dataset of locations where radar surveys performed between 2012 and 2017 suggested possible breeding activity (Brown 2017). We then calculated the mean suitability values at survey locations in each dataset.

\section{Habitat availability and habitat loss}

Because the habitat suitability model was built using tree cover data for 2000 , we calculated the total area of predicted habitat suitable for nesting Black-capped Petrels in Hispaniola in 2018 by subtracting areas where forest loss occurred during 2000-2018 from the Black-capped Petrel habitat suitability raster. We used Google Earth Engine to obtain spatial datasets of total forest loss (Hansen Global Forest Change v1.6: 2000-2018; Hansen et al. 2013). Similarly, we also estimated changes in the availability of predicted habitat due to forest loss during the periods 
2000-2015 and 2015-2018. We chose 2015 as a cut-off because it is the year when most nest sites were located, and the median year for all nest searches. We estimated the total area and proportion of predicted suitable nesting habitat lost to forest loss during 2000-2015 and 2015-2018, for predicted suitability levels above the specificity-sensitivity threshold and $>0.9$. Areas calculated directly from the habitat suitability raster (i.e. two-dimensional areas) would fail to account for the topography of the landscape; therefore, we calculated landscape surface areas on the basis of the DEM (Jenness 2004), using the surfaceArea function in R (package $s p$ ) for both suitability levels.

\section{Results}

Combining overlapping presence polygons and combining overlapping pseudo-absence polygons resulted in sample sizes of $n=23$ presence polygons, with a mean area of $11.1 \times 10^{3} \mathrm{~m}^{2}$ (range: 7.8

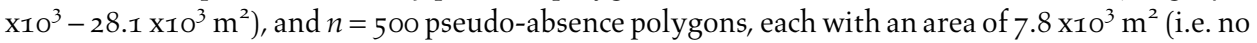
pseudo-absence buffers overlapped). Of the 14 environmental covariates that we compared individually between presence and pseudo-absence sites, six differed significantly and, of those, three were retained for use in generalized linear models $(P \leq$ o.or for each; Table 2$)$.

The predicted suitability of a site for breeding Black-capped Petrels increased with elevation and tree cover-EVI. In contrast, sites were less suitable as distance to coast increased and as EVI increased. Of the eight models assessed, one clearly performed as the top-ranked model. The model that included each of the three retained variables (elevation, distance from site to coast, and tree cover-EVI) carried $99.9 \%$ of the model weights (Table 3). Elevation was the strongest contributor to the model (null model: residual deviance $=61.00$; elevation: residual deviance $=$ 39.15 , deviance $=21.85, \operatorname{pr}(>\mathrm{Chi})<0.005)$, followed by distance to coast $($ residual deviance $=27.95$, deviance $=11.20, \operatorname{pr}(>\mathrm{Chi})<0.005)$, and tree cover-EVI (residual deviance $=21.68$, deviance $=6.26$, $\operatorname{pr}(>\mathrm{Chi})<0.05)$. The top model had a continuous Boyce Index of 0.63 , suggesting that model predictions were consistent with the distribution of presence locations in our validation dataset. The dataset had a spatial sorting bias of 0.43 , indicating a moderate spatial correlation. The top model had a specificity of 0.63 , a sensitivity of 0.71 , and the threshold of specificity-sensitivity had a value of 0.65 (Figure 2).

The presence and pseudo-absence datasets retained for validation had significantly different distributions $\left(\mathrm{F}_{11,100}=0.12, P<0.005\right)$. The presence dataset had a mean predicted suitability value of 0.88 (range: $0.65-0.98$; Figure 2) while the pseudo-absence dataset had a mean predicted suitability value of 0.15 (range: 0.00-0.97; Figure 2). Results suggest that known Black-capped Petrel nesting sites were classified correctly by our model (i.e. predicted suitability values $>0.65$ ). Most sites where petrel activity had been recorded based on other surveys were also classified correctly (Table 4).

Our model suggested that the higher elevations of Massif de la Hotte, Massif de la Selle, Sierra de Bahoruco, and the south-east Cordillera Central are suitable for nesting Black-capped Petrels (Figure 3, Figure S1; Table 5). The higher elevations of the lower foothills to the southeast of Sierra de Bahoruco also appear highly suitable (Figures 3 and $\mathrm{S}_{1}$ ). In contrast, Sierra de Neiba and the entirety of the occidental Cordillera Central do not appear suitable for nesting Black-capped Petrels.

Our models also identified the extent of predicted nesting habitat lost since 2000. In 2018, $563 \mathrm{~km}^{2}$ (suitability $>0.65$ ) and $167 \mathrm{~km}^{2}$ (predicted suitability $>0.9$ ) were available to nesting Black-capped Petrels in Hispaniola (Figures 3 and S2). The majority of predicted suitable areas were located in the Dominican Republic (c.75\%; Table 5). Between 2000 and 2015, there was a decline of $6.3 \%\left(>0.65 ; 41.9 \mathrm{~km}^{2}\right)$ and $3.9 \%\left(>0.9 ; 7.8 \mathrm{~km}^{2}\right)$ of the predicted habitat originally available in 2000 due to forest loss (see Hansen et al. 2013 for definition of forest loss); between 2015 and 2018 , there was a decline of $9.9 \%\left(>0.65 ; 61.6 \mathrm{~km}^{2}\right)$ and $13.3 \%\left(>0.9 ; 25.6 \mathrm{~km}^{2}\right)$ of the predicted habitat available in 2015 due to forest loss. Overall, between 2000 and 2018 , there was a decline of $15.5 \%\left(>0.65 ; 103.5 \mathrm{~km}^{2}\right)$ and $16.7 \%\left(>0.9 ; 33.4 \mathrm{~km}^{2}\right)$ of the predicted habitat available in 2000 on Hispaniola due to forest loss (Figure 4). Forest loss primarily affected the Massif de la Hotte, 


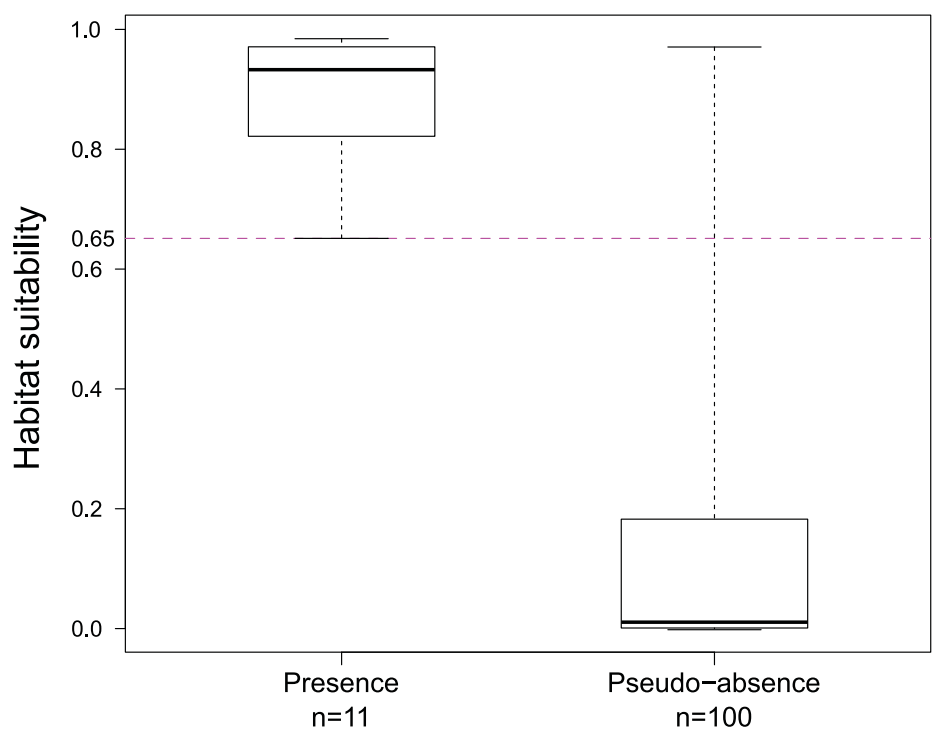

Figure 2. Distribution of predicted habitat suitability values for presence and pseudo-absence sites for Black-capped Petrel on Hispaniola. Solid lines within boxes represent the median, edge of boxes represent quartiles, and whiskers extend to $5^{\text {th }}$ and $95^{\text {th }}$ percentiles. The threshold of specificitysensitivity is shown with a dashed line.

Table 4. Proportion of sites from a validating dataset of existing nest sites, and from datasets of acoustic monitoring and radar surveys correctly classified as suitable by the Black-capped Petrel nesting habitat suitability model on Hispaniola. Proportions are calculated as the percentage of sites with predicted suitability values above the suitability threshold.

\begin{tabular}{lccc}
\hline & \multicolumn{2}{c}{ Proportion of sites correctly classified as suitable (\%) } \\
\cline { 2 - 4 } Suitability threshold & $\begin{array}{c}\text { Nest sites } \\
n=11\end{array}$ & $\begin{array}{c}\text { Acoustics } \\
n=4\end{array}$ & $\begin{array}{c}\text { Radar } \\
n=6\end{array}$ \\
\hline$>0.5$ & 100.0 & 100.0 & 66.7 \\
$>0.6$ & 100.0 & 100.0 & 50.0 \\
$>0.65$ & 100.0 & 100.0 & 50.0 \\
$>0.7$ & 81.8 & 75.0 & 50.0 \\
$>0.8$ & 72.7 & 75.0 & 33.3 \\
$>0.9$ & 72.7 & 50.0 & 16.7 \\
\hline
\end{tabular}

Cordillera Central, and Sierra de Bahoruco with $66.9 \%, 12.9 \%$, and $11.0 \%$ of predicted suitable habitat (>0.9) lost in each area between 2000-2018, respectively (Table 5).

\section{Discussion}

Our study provides details on the large-scale habitat characteristics of Black-capped Petrel nesting areas, locates the main suitable areas for the species in Hispaniola, and estimates the extent of the remaining suitable habitat. We documented significant selection for abiotic (elevation and distance to coast) and biotic (EVI and tree cover) habitat features. Our detailed predictive map of Blackcapped Petrel habitat suitability located highly suitable habitat in all four elevated areas of Hispaniola where the species is currently known to nest, and in nearby surrounding areas at lower 


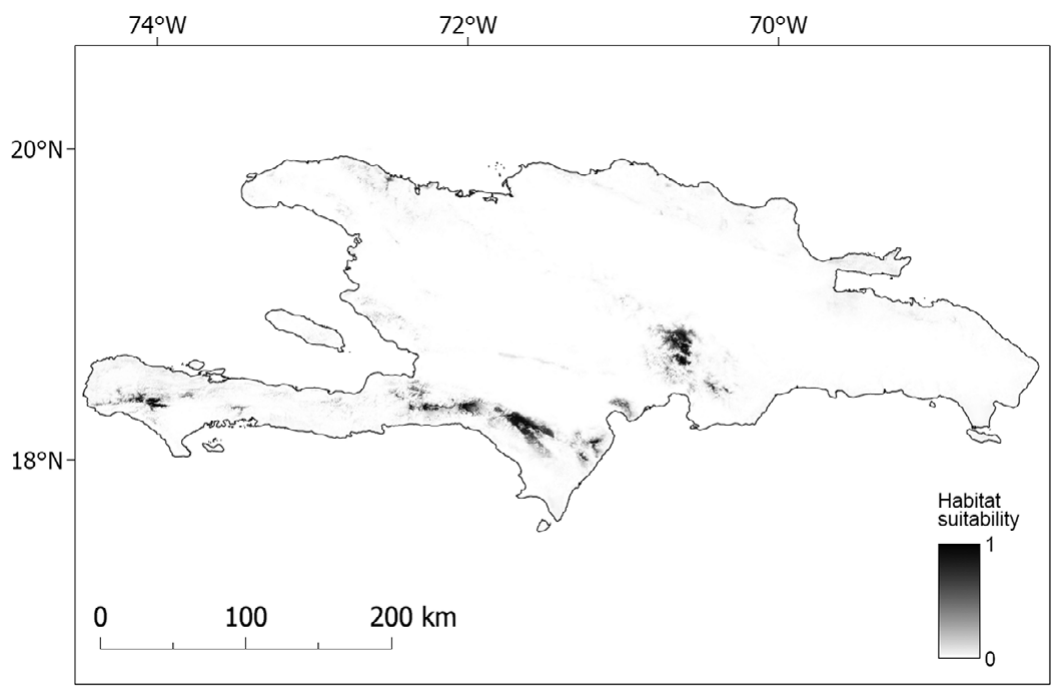

Figure 3. Map of predicted nesting habitat suitability for Black-capped Petrel on Hispaniola. Areas most suitable for nesting Black-capped Petrels are shown in black. A larger version of this figure is provided as a georeferenced file of 90-m pixel resolution in Figure $\mathrm{S}_{2}$ (https://doi.org/10.5066/P9FWJPBD). A version of this figure showing only the suitable (predicted suitability $>0.65$ ) and most highly suitable habitats (predicted suitability $>0.9$ ) are available in Figure $\mathrm{S}_{3}$ (https://doi.org/10.5066/P9FWJPBD).

Table 5. Total area of predicted suitable habitat currently available for nesting Black-capped Petrel, and amount and proportion of habitat lost to forest loss during 2000-2018 at the four main nesting areas on Hispaniola.

\begin{tabular}{lrrrrrrrrr}
\hline & \multicolumn{2}{c}{$\begin{array}{l}\text { Massif de la } \\
\text { Hotte }\end{array}$} & \multicolumn{2}{c}{$\begin{array}{c}\text { Massif de la } \\
\text { Selle }\end{array}$} & \multicolumn{2}{c}{$\begin{array}{c}\text { Sierra de } \\
\text { Bahoruco }\end{array}$} & \multicolumn{2}{c}{ Valle Nuevo } \\
\cline { 2 - 9 } Suitability threshold & \multicolumn{2}{c}{0.65} & $>0.9$ & $>0.65$ & $>0.9$ & $>0.65$ & $>0.9$ & $>0.65$ & $>0.9$ \\
\hline Current suitable area $\left(\mathrm{km}^{2}\right)$ & & 36.9 & 10.4 & 108.4 & 51.4 & 182.7 & 55.6 & 184.1 & 47.3 \\
Habitat lost to forest loss & $\mathrm{km}^{2}$ & 46.6 & 21.0 & 4.2 & 1.6 & 23.2 & 3.8 & 26.0 & 7.0 \\
& $\%$ & 55.8 & 66.9 & 3.8 & 3.0 & 11.0 & 6.3 & 21.4 & 12.9 \\
\hline
\end{tabular}

elevations. We also found that predicted suitable habitat is absent from the occidental Cordillera Central. Finally, we calculated the decline in predicted suitable nesting habitat of Black-capped Petrel due to forest loss throughout the last decade.

\section{Environmental variables}

Elevation was the strongest predictor in our generalized linear model, with nests occurring c. 2,100 $\mathrm{m}$ above sea level. A preference for higher elevation nest sites is consistent with other species of gadfly petrels (Zino et al. 2001, Rayner et al. 2007, Pinet et al. 2009, Scott et al. 2009, Troy et al. 2017). Black-capped Petrels may nest at higher elevations to avoid predation by introduced mammalian predators (Simons et al. 2013), which appear to be more common at lower elevations, or to avoid anthropogenic disturbances including deforestation. However, unlike other tropical and subtropical petrel species (Rayner et al. 2007, Pinet et al. 2009, Scott et al. 2009, Troy et al. 2017, Krüger et al. 2018), nesting sites of Black-capped Petrels did not appear to be located more on areas 


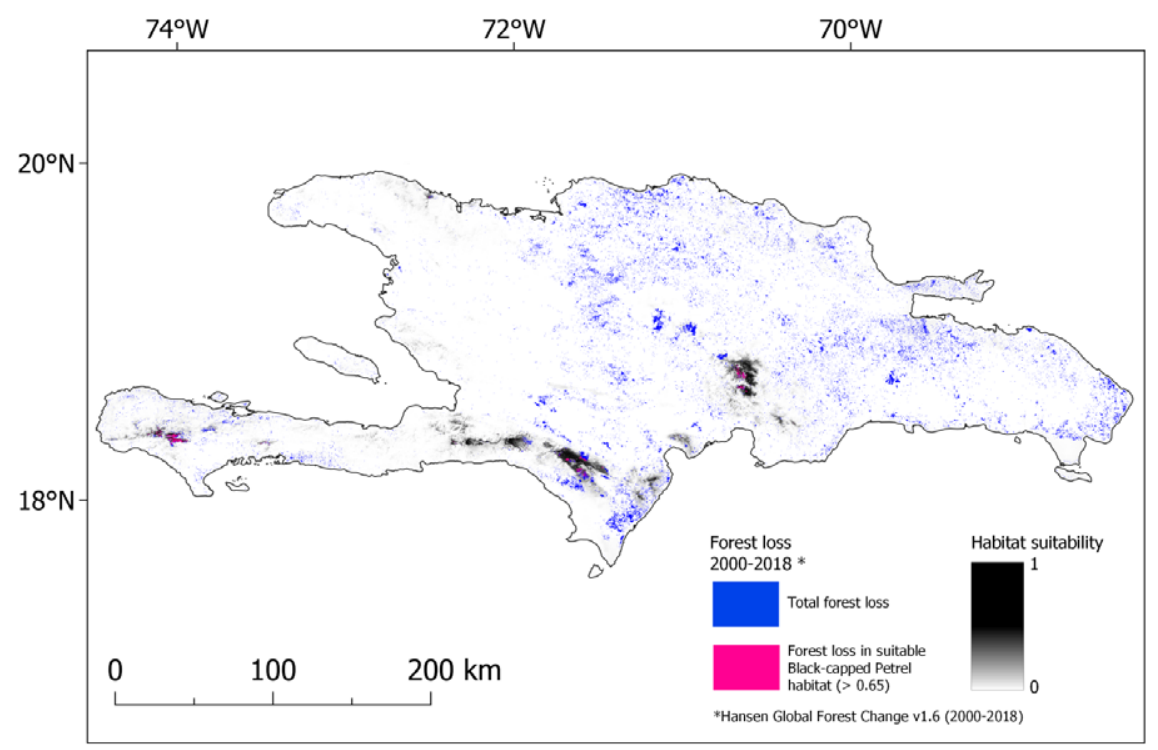

Figure 4. Map of forest lost during 2000-2018 overlaid on nesting habitat suitability for Blackcapped Petrel on Hispaniola. Forest loss that occurred in habitat suitable for Black-capped Petrel (> o.65) is shown in pink; forest loss that occurred elsewhere in Hispaniola is shown in blue. A color version of this figure may be found in the electronic version of this article.

with steep slopes than on less steep areas. In their study of Cory's shearwaters Calonectris borealis, Oppel et al. (2014) found that nests tended to occur either on vertical cliffs or less steep areas, but not at sites with intermediate slopes. Similarly, known nest sites for Black-capped Petrels have either been located on extremely steep slopes in Haiti, or in varied mountainous terrain (varied slopes, flat ridges, bottom of thalwegs) in the Dominican Republic. As with elevation, the occurrence of nesting sites on steep slopes in Haiti may be more a consequence of anthropogenic disturbances than intentional selection, where extremely steep terrain creates a refuge from agriculture. Thus, habitat availability due to regional variation in mountainous terrain may outweigh any potential selectivity based on slope.

Known nesting sites of Black-capped Petrels were associated with increased tree cover-EVI, and decreased EVI. An ad hoc composite variable, tree cover-EVI provides information on the forest structure, while the stand-alone EVI provides information on the type and richness of the vegetation. The intermediate EVI values associated with nesting areas, while representative of mature forested areas, are typically associated with sparser green vegetation and intermediate tree richness (in comparison, dense rainforests and diverse forests have higher EVI values; Waring et al. 2006). Therefore, our results suggest that, at the macro-habitat level, Black-capped Petrels nest in productive forests with undergrowth and greater canopy cover but appear to prefer drier pine forests rather than dense cloud-forests. Camera trapping and lost feathers suggest that petrels sometimes take off directly from the ground after selecting a suitable location near an opening in the canopy. Thus, the thin canopy cover of pine forests may ease access to and from nesting sites. However, our model may be influenced by the habitat types associated with the highest frequency of nests. For example, a larger proportion of nest sites have been located in the Sierra de Bahoruco, a karstic mountain range characterized by forests of Hispaniolan Pine Pinus occidentalis in uniform stands (i.e. drier pine forest) or mixed with evergreen broadleaf species (Darrow and Zanoni 1990, ESA Climate Change Initiative 2019). Areas with differing but potentially suitable vegetation 
communities (e.g. broadleaf forests interspersed with Hispaniolan Pines in Valle Nuevo, and shrub-like broadleaf vegetation with few large trees on steep slopes in La Visite) have not yet been searched as extensively. Therefore, as searches for additional nesting sites are ongoing, it would be valuable to improve this habitat suitability model with the inclusion of new nesting locations in differing habitats.

Nest sites of Black-capped Petrels were associated with areas closer to the coastline (mean = $25.4 \mathrm{~km}$ ). Since all known nest sites have been located within c. $30 \mathrm{~km}$ of the nearest coastline, our model was strongly influenced by nest sites within close range of the coast. This may partly explain why two central mountainous areas on Hispaniola suspected to host Black-capped Petrels (Sierra de Neiba and occidental Cordillera Central) are not categorized as suitable by our model. Black-capped Petrels typically fly at sustained speeds of $15-49 \mathrm{~km} / \mathrm{h}$ at sea (Jodice et al. 2015, Satgé et al. 2019) and above $50 \mathrm{~km} / \mathrm{h}$ over land (Brown 2016) and may rapidly reach any location in Hispaniola. Other seabirds do nest far inland: recently, a nesting area of the Hornby's Storm-petrel Oceanodroma hornbyi has been discovered c.75 km from the coastline (Barros et al. 2018); Marbled murrelets Brachyramphus marmoratus may nest up to $90 \mathrm{~km}$ away from the coast (Hamer 1995); and inland colonies of Antarctic petrels Thalassoica antarctica can be located $>200 \mathrm{~km}$ from the nearest open water (van Franeker et al. 1999). However, radar surveys of the central mountain ranges on Hispaniola suggest that, although petrels may reach the areas, they do not breed there (Brown 2014). Furthermore, distance to coast was not the strongest predictor in our model, which was most strongly influenced by elevation. In fact, distance to coast and tree cover-EVI had a smaller deviance between each other than distance to coast had with elevation. This suggests that it is the combined influence of distance and vegetation type, more so than higher detection of nest sites in more coastal areas, that identified the central mountain ranges as not suitable for nesting Black-capped Petrels.

\section{Location of suitable habitat}

The only existing assessment of potential nesting habitat for the Black-capped Petrel (Leon, cited in U.S. Fish and Wildlife Service 2018) calculated a maximum potential area of $2,343 \mathrm{~km}^{2}$ based solely on elevation (all habitat on Hispaniola $\geq 1,500 \mathrm{~m}$ above sea level). By using environmental predictors, we refined the estimate in Leon (U.S. Fish and Wildlife Service 2018) to include suitable habitat below and above $1,500 \mathrm{~m}$. Our most liberal estimate of potential nesting habitat is $563.3 \mathrm{~km}^{2}$ (predicted suitability $>0.65$ ), with our most conservative predictions indicating that the most suitable habitat is limited to a total area of $167.1 \mathrm{~km}^{2}$ (predicted suitability > 0.9). Our model correctly located the four known major nesting areas. Among them, areas in Haiti (Massif de la Hotte and Massif de la Selle) are the most limited in size $\left(145.3 \mathrm{~km}^{2}\right.$, predicted suitability $>0.65$; c. $25 \%$ of the predicted suitable habitat on Hispaniola). In the Dominican Republic, $366.8 \mathrm{~km}^{2}$ are predicted to be available $(>0.65)$. This difference in available habitat between the two nations is due in part to the preponderance of mountainous areas in the Dominican Republic compared to Haiti. Further, most forested areas in Haiti have been cut throughout the $2 \mathrm{O}^{\text {th }}$ century and prior to the baseline year (2000) of our analysis (Hedges et al. 2018), thus effectively reducing the extent of mature forests to high mountain tops and steep slopes (Hedges et al. 2018).

In Haiti, the predicted suitable areas for nesting Black-capped Petrels are located on the slopes and cirques of massifs de la Hotte and de la Selle. The steep north-facing slopes of the La Visite escarpment and banks of steep valleys descending from Pic de la Selle were also classified as highly suitable. In the Dominican Republic, most of the predicted suitable habitat occurs in the Sierra de Bahoruco and Cordillera Central ranges and covers the higher elevations of both massifs. Predicted suitable habitat is also available on lower foothills of the oriental Sierra de Bahoruco. A further detailed description of the location of predicted suitable habitat in Haiti and the Dominican Republic is available in Appendix S2. 


\section{Habitat loss}

Our study shows that forest loss was the cause of a significant decline in the amount of predicted suitable habitat for nesting Black-capped Petrels in Hispaniola between 2000 and 2018. Although the reasons for forest loss were not explicit in the dataset we used (Hansen et al. 2013), we suggest that three main causes are responsible for the majority of the loss on Hispaniola: hurricanes, forest fires, and deforestation. Habitat loss was not consistent among all years and the source data we used (Hansen et al. 2013) indicate that forest loss was nearly double from 2015 to 2018 compared to 2000-2015. Most of the habitat loss during 2015-2018 occurred in the Massif de la Hotte, where $55.8 \%\left(46.6 \mathrm{~km}^{2}\right)$ of the predicted suitable nesting habitat $(>0.65)$ was lost during the last quarter of 2016 (Global Forest Watch 2019b). This swift event was likely caused by Hurricane Matthew, a major hurricane of category 4 which made landfall on the Haitian coast c.5o km east of La Hotte and caused extensive damage (Stewart 2017). Black-capped Petrels are thought to have adapted their phenology to avoid nesting and rearing chicks during the hurricane season (Simons et al. 2013). However, due to the loss or degradation of forest habitat caused by large storms, hurricanes are causes of concern for the resiliency of the species: the U.S. Fish and Wildlife Service (2018) has listed the increase of hurricane intensity and frequency due to climate change as a major threat to the viability of the Black-capped Petrel population. Since no nesting sites have been located in the Massif de la Hotte, Hurricane Matthew would not have impacted the statistical correlation between nesting sites and environmental predictors, or the resulting equation used in our habitat model. Nevertheless, it could have decreased the amount of predicted habitat that was categorized as suitable by our model in the area, thus more suitable habitat may have been available for nesting Black-capped Petrel in the Massif de la Hotte than predicted in our study.

In the Dominican Republic, the predicted suitable habitats of Sierra de Bahoruco and Cordillera Central appear to have been affected by several forest fires from 2006 to 2016 (Global Forest Watch 2019b, Lloyd and León 2019). Natural forest fires are recurrent events in dry forests of Hispaniola Pine and, to an extent, may be beneficial for Black-capped Petrels in creating the open overstorey needed to easily access and leave nesting sites (Simons et al. 2013). However, fires strong enough to affect the canopy of Hispaniolan Pines, and thus be recorded as forest loss in satellite imagery, are likely to also cause extensive damage to the forest floor and understorey, hence affecting the mesic microhabitat needed by Black-capped Petrels to nest.

Finally, to a lesser, but more persistent extent than hurricanes or natural forest fires, deforestation for agriculture appears to have impacted predicted Black-capped Petrel habitat in both countries. In particular, illegal deforestation appears to occur regularly in petrel habitat within the boundaries of the La Visite (Brown pers. obs.), Sierra de Bahoruco and Valle Nuevo national parks (Lloyd and León 2019, Rupp pers. obs.). In La Visite, deforestation is limited by the extreme slopes of observed petrel habitat but occurs on the periphery of predicted suitable habitat. In Sierra de Bahoruco, avocado plantations are progressing inside the national park boundaries and reaching the lower fringe of predicted suitable habitat, while in Valle Nuevo, farming of cash crops is occurring within hundreds of meters of the recently discovered nesting sites (Rupp pers. obs.). In Hispaniola, national parks offer some level of protection but are often not entirely effective at protecting against small scale deforestation and accumulated encroachment (Sangermano et al. 2015, Hedges et al. 2018, Lloyd and León 2019). Although the areas currently lost to deforestation represent only a small fraction of the predicted suitable habitat for Black-capped Petrels and of the overall protected areas in Hispaniola, anthropogenic activities may create additional disturbances beyond habitat loss (e.g. lighted buildings, noise, fires, collection of firewood in nesting habitat) and subsequently attract mammalian predators (e.g. rats, cats, dogs, mongoose) into nesting areas. Moreover, our estimation of habitat loss only accounts for predicted habitat that was directly changed. Predicted habitat that may have been encroached upon or disturbed and made less suitable for Black-capped Petrels may not have been captured in our analysis. Therefore, we suggest that our results represent a minimum estimate of habitat loss. 


\section{Conclusion}

Our study characterizes the macro habitat for nesting Black-capped Petrels in Hispaniola and demonstrates that available suitable habitat has been increasingly impacted by natural and anthropogenic forest loss over the last two decades. The results of our study can inform searches for unknown nesting areas in Hispaniola and can be applied to other islands in the region where the species is suspected to breed. Finally, our results demonstrate that conservation of the mountainous habitat of Hispaniola would benefit the species by protecting habitat suitable for nesting. Given that other globally rare and vulnerable species use similar habitat, such as Bicknell's Thrush Catharus bicknelli (McFarland et al. 2013) and Hispaniolan Solenodon Solenodon paradoxus (Rodríguez 201I), conservation actions applied in these regions may have multi-species benefits.

\section{Supplementary Materials}

To view supplementary material for this article, please visit http://dx.doi.org/10.1017/ So959270920000490.

\section{Acknowledgements}

We thank Theodore Simons and two anonymous reviewers who improved earlier versions of this manuscript. Support for this analysis was provided by the South Carolina Cooperative Fish and Wildlife Research Unit and Clemson University. In addition to the institutions of the authors, nest searches were supported by the American Bird Conservancy, the U.S. Fish and Wildlife Service, Cornell University, Disney Conservation, and the BirdsCaribbean Betty Petersen Fund for Conservation. In addition to the authors, nest sites used in this study were located by James E. Goetz, Esteban Garrido, Anderson Jean, René Jeune, Tinio Louis, Lionel Raymond, Jonel Bazil, Pirrín Jairo Matos, Gerson Feliz, José Luis Castillo, and Ivan Terrero. We thank members of the International Black-capped Petrel Conservation Group for helpful comments at all stages of the analysis. Permits for field research were provided by the Ministerio de Medio Ambiente y Recursos Naturales de la República Dominicana, and the Ministère de l'Environnement de la République d'Haïti. The South Carolina Cooperative Fish and Wildlife Research Unit is supported by the South Carolina Department of Natural Resources, Clemson University, the US Fish and Wildlife Service, and the US Geological Survey. Any use of trade, firm, or product names is for descriptive purposes only and does not imply endorsement by the US government.

\section{References}

Barbet-Massin, M., Jiguet, F., Albert, C. H. and Thuiller, W. (2012) Selecting pseudoabsences for species distribution models: how, where and how many? Meth. Ecol. and Evol. 3: 327-338.

Barros, R., Medrano, F., Silva, R. and de Groote, F. (2018) First breeding site record of Hornby's Storm Petrel Oceanodroma hornbyi in the Atacama Desert, Chile. Ardea 106: 203-208.

BirdLife International (2016) Pterodroma hasitata. The IUCN Red List of Threatened Species 2016. e.T22698092A93660424

BirdLife International.(2018) Species factsheet: Pterodroma hasitata [on-line]. Downloaded from http://www.birdlife.org on 15 September 2019.

Brown, A. (2014) Radar Surveys for Blackcapped Petrels on Hispaniola: January March 2014. Green Cove Spring, Florida, USA: Environmental Protection In the Caribbean.

Brown, A. (2015) Radar surveys for the Endangered Black-capped Petrel on Dominica, West Indies. Report to the Dominica Department of Agriculture, Forestry and Parks Division, Dominica... Green Cove Spring, Florida, USA: Environmental Protection In the Caribbean. 
Brown, A. (2016) Radar surveys for petrels in Jamaica: Results from an expedition during March 2016. Report to the National Environment and Planning Agency, Jamaica... Green Cove Spring, Florida, USA: Environmental Protection In the Caribbean.

Brown, A. (2017) Radar Surveys, Nest Monitoring and Conservation of the Blackcapped Petrel on Hispaniola: February $2017 \ldots$ Green Cove Spring, Florida, USA: Environmental Protection In the Caribbean. Collar, N. J., Gonzaga, L. P., Krabbe, N., Madroño Nieto, A., Naranjo, L.G., Parker, T.A. and Wege, D. C. (1992) Threatened birds of the Americas: the ICBP/IUCN Red Data Book... Cambridge, UK: International Council for Bird Preservation.

Croxall, J. P., Butchart, S. H., Lascelles, B., Stattersfield, A. J., Sullivan, B., Symes, A. and Taylor, P. (2012) Seabird conservation status, threats and priority actions: a global assessment. Bird Conserv. Internatn. 22: 1-34.

Darrow, W. K. and Zanoni, T. (1990) Hispaniolan pine (Pinus occidentalis Swartz) a little known sub-tropical pine of economic potential. Commonwealth Forest. Rev. 69: 133-146.

Dias, M. P., Martin, R., Pearmain, E. J., Burfield, I. J., Small, C., Phillips, R. A., Yates, O., Lascelles, B., Borboroglu, P. G. and Croxall, J. P. (2019) Threats to seabirds: a global assessment. Biol. Conserv. 237: 525-537.

Elith, J. and Leathwick, J. R. (2009) Species distribution models: ecological explanation and prediction across space and time. Annu. Rev. Ecol. Evol. S. 40: 677-697.

ESA Climate Change Initiative (2019) Land Cover project 2017: Land Cover Map v2.o.7. Accessed online at https://maps. elie.ucl.ac.be/CCI/viewer/ on 15 November 2019.

Fick, S. E. and Hijmans, R. J. (2017) WorldClim 2: new $1-\mathrm{km}$ spatial resolution climate surfaces for global land areas. Int. J. Climatol. 37: 4302-4315.

Fleishman, A. B. and McKown, M. (2017) Acoustic surveys for Black-capped Petrel Valle Nuevo, Hispaniola - 2016-17 - Final Report. Santa Cruz, California, USA: Conservation Metrics, Inc.

van Franeker, J. A., Gavrilo, M., Mehlum, F., Veit, R. R. and Woehler, E. J. (1999)
Distribution and abundance of the Antarctic Petrel. Waterbirds 22: 14-28.

Global Forest Watch. (2019a) Tree cover (2000) [on-line]. Updated 2 April 2019. Downloaded from http://data.globalforestwatch.org on 5 April 2019.

Global Forest Watch. (2019b) Tree cover loss 2001-2018 (Version 1.6) [on-line]. Accessed online at http://data.globalforestwatch.org on [15 November 2019].

Global Forest Watch. (2019c) Aboveground live woody biomass density [on-line]. Updated 2 April 2019. Downloaded from http://data.globalforestwatch.org on 5 April 2019.

Goetz, J. E., Norris, J. H. and Wheeler, J. A. (2012) Conservation Action Plan for the Black-capped Petrel (Pterodroma hasitata). International Black-capped Petrel Conservation Group. http://www.fws.gov/birds/ waterbirds/petrel

Hamer, T. E. (1995) Inland habitat associations of Marbled Murrelets in western Washington. Pp. 163-176 in J. C. Ralph, ed. Ecology and conservation of the Marbled Murrelet. Gen. Tech. Rep. PSW-GTR152. Albany, California, USA: Pacific Southwest Research Station, Forest Service, US Department of Agriculture.

Hansen, M. C., Potapov, P. V., Moore, R., Hancher, M., Turubanova, S. A. A., Tyukavina, A., Thau, D., Stehman, S. V., Goetz, S. J., Loveland, T. R. and Kommareddy, A. (2013) High-resolution global maps of 21stcentury forest cover change. Science 342 : 850-853. Data available on-line at: http:// earthenginepartners.appspot.com/science2013-global-forest.

Hedges, S. B., Cohen, W. B., Timyan, J. and Yang, Z. (2018) Haiti's biodiversity threatened by nearly complete loss of primary forest. P. Natl. Acad. Sci. USA 115: 11850-11855.

Hijmans, R. J. (2012) Cross-validation of species distribution models: removing spatial sorting bias and calibration with a null model. Ecology 93: 679-688.

Hirzel, A. H., Le Lay, G., Helfer, V., Randin, C. and Guisan, A. (2006) Evaluating the ability of habitat suitability models to predict species presences. Ecol. Model. 199: 142-152.

Jean, A., Louis, T., Jeune, R., Raymond, L. and Brown, A. (2018) Black-capped Petrel Nest 
Monitoring in Parc National La Visite, Haiti: 2018 Breeding Season. Green Cove Spring, Florida, USA: Environmental Protection In the Caribbean.

Jenness, J. S. (2004) Calculating landscape surface area from digital elevation models. Wildlife Soc. Bull. 32: 829-839.

Jodice P. G. R, Ronconi, R. A., Rupp, E., Wallace, G. E., and Satgé, Y. (2015) First satellite tracks of the Endangered Blackcapped Petrel. Endanger. Species Res. 26: 23-33.

Krüger, L., Paiva, V. H., Petry, M. V., Montone, R. C. and Ramos, J. A. (2018) Population estimate of Trindade Petrel Pterodroma arminjoniana by the use of predictive nest habitat modelling. Bird Conserv. Internatn. 28: 197-207.

Lloyd, J. D. and León, Y. (2019) Forest change within and outside protected areas in the Dominican Republic, 2000-2016. BioRxiv: 558346.

Lobo, J. M., Jiménez-Valverde, A. and Real, R. (2008) AUC: a misleading measure of the performance of predictive distribution models. Global Ecol. Biogeogr. 17: 145-151.

McFarland, K. P., Rimmer, C. C., Goetz, J. E., Aubry, Y., Wunderle Jr, J. M., Sutton, A., Townsend, J. M., Sosa, A. L. and Kirkconnell, A. (2013) A winter distribution model for Bicknell's Thrush (Catharus bicknelli), a conservation tool for a threatened migratory songbird. PloS ONE. 8: 53986.

McKown, M., Fleishman, A. B., Earl, A. D. (2016) Acoustic surveys for Black-capped Petrel on Hispaniola and Dominica $2016 \ldots$ Santa Cruz, California, USA: Conservation Metrics, Inc.

Oppel, S., Hervias, S., Oliveira, N., Pipa, T., Silva, C., Geraldes, P., Goh, M., Immler, E. and McKown, M. (2014) Estimating population size of a nocturnal burrow-nesting seabird using acoustic monitoring and habitat mapping. Nat. Conserv. 7: 1-13.

Paleczny, M., Hammill, E., Karpouzi, V. and Pauly, D. (2015) Population trend of the world's monitored seabirds, 1950-2010. PLoS ONE 10(6): e0129342.

Pinet, P., Salamolard, M., Probst, J. M., Russell, J. C., Jaquemet, S. and Le Corre, M. (2009) Barau's Petrel Pterodroma baraui: history, biology and conservation of an endangered endemic petrel. Mar. Ornithol. 37: 107-113.

Quinn, G. P. and Keough, M. J. (2002) Experimental design and data analysis for biologists. Cambridge, UK: Cambridge University Press.

Ramos, R., Carlile, N., Madeiros, J., Ramírez, I., Paiva, V. H., Dinis, H. A., Zino, F., Biscoito, M., Leal, G. R., Bugoni, L. and Jodice, P. G. (2017) It is the time for oceanic seabirds: Tracking year-round distribution of gadfly petrels across the Atlantic Ocean. Divers. Distrib. 23: 794-805.

Rayner, M. J., Clout, M. N., Stamp, R. K., Imber, M. J., Brunton, D. H. and Hauber, M. E. (2007) Predictive habitat modelling for the population census of a burrowing seabird: a study of the endangered Cook's petrel. Biol. Conserv. 138: 235-247.

Rodríguez, R. A. P. (2011) Habitat-species association in the Hispaniolan Solenodon (Solenodon paradoxus): A quantitative study of an Endangered Caribbean mammal PhD dissertation Department of Life Sciences, Silwood Park, Imperial College London.

Rodríguez, A., Arcos, J. M., Bretagnolle, V., Dias, M. P., Holmes, N. D., Louzao, M., Provencher, J., Raine, A. F., Ramírez, F., Rodríguez, B. and Ronconi, R. A. (2019) Future directions in conservation research on petrels and shearwaters. Front. Mar. Sci. 6: 1-27.

Sangermano, F., Bol, L., Galvis, P., Gullison, R. E., Hardner, J. and Ross, G. S. (2015) Habitat suitability and protection status of four species of amphibians in the Dominican Republic. Appl. Geogr. 63: 55-65.

Satgé, Y. G., Rupp, E. and Jodice, P. G. R. (2019) A preliminary report of ongoing research of the ecology of Black-capped Petrel (Pterodroma hasitata) in Sierra de Bahoruco, Dominican Republic - I: GPS tracking of breeding adults... Clemson, South Carolina, USA: South Carolina Cooperative Research Unit, Clemson University.

Scott, D., Moller, H., FletcHer, D., Newman, J., Aryal, J., Bragg, C. and Charleton, K. (2009) Predictive habitat modelling to estimate petrel breeding colony sizes: sooty shearwaters (Puffinus griseus) and mottled petrels (Pterodroma inexpectata) on Whenua Hou Island. NZ J. Zool. 36: 291-306. 
Simons, T. R., Lee, D. S., and Haney, J. C. (2013) Diablotin Pterodroma hasitata: a biography of the endangered Black-capped Petrel. Mar. Ornithol. 41: $\mathrm{S}_{3}-\mathrm{S}_{43}$.

Stewart, S. R. (2017) National Hurricane Centre Tropical cyclone report: Hurricane Matthew (AL142016)... Miami, Florida, USA: National Oceanic and Atmospheric Administration National Weather Service.

Troy, J. R., Holmes, N. D., Veech, J. A., Raine, A. F., and Green, M. C. (2014) Habitat suitability modelling for the Newell's shearwater on Kauai. J. Fish Wildl. Manage. 5: 315329.

Troy, J. R., Holmes, N. D., Veech, J. A., Raine, A. F., and Green, M. C. (2017) Habitat suitability modeling for the endangered Hawaiian petrel on Kauai and analysis of predicted habitat overlap with the Newell's shearwater. Global Ecol. Cons. 12: 131-143.

U.S. Fish and Wildlife Service. (2018) Species status assessment report for the Blackcapped Petrel (Pterodroma hasitata). Version 1.1. Atlanta, Georgia, USA: U.S. Fish and Wildlife Service.
Warham, J. (1990) The petrels: their ecology and breeding systems. London, UK: Academic Press.

Waring, R. H., Coops, N. C., Fan, W. and Nightingale, J. M. (2006) MODIS enhanced vegetation index predicts tree species richness across forested ecoregions in the contiguous USA. Remote Sens. Environ. 103: 218-226.

Warren, D. L., Matzke, N. J. and Iglesias, T. L. (2020) Evaluating presence-only species distribution models with discrimination accuracy is uninformative for many applications. J. Biogeogr. 47:167-180.

Wessel, P. and Smith, W. H. (2017) A global, selfconsistent, hierarchical, high-resolution shoreline database [on-line]. Updated June 15, 2017. Downloaded from https://www.soest.hawaii. edu/pwessel/gshhg/ on I June 2018.

Wingate, D. B. (1964) Discovery of breeding Black-capped Petrels on Hispaniola. Auk. 81: 147-159.

Zino, F., Oliveira, P., King, S., Buckle, A., Biscoito, M., Neves, H. C. and Vasconcelos, A. (2001) Conservation of Zino's petrel Pterodroma madeira in the archipelago of Madeira. Oryx 35: 128-136. 